\title{
Financialization of Green Capital: A Panacea?
}

\author{
Mabutho Sibanda, PhD \\ Lecturer-School of Accounting, Economics \& Finance, \\ University of KwaZulu-Natal, South Africa \\ Email: sibandam@ukzn.ac.za
}

\section{Doi:10.5901/mjss.2013.v4n6p371}

\section{Abstract}

Climate financing (green financing) is currently attracting a lot of attention as governments, private sector, multilateral institutions and the donor community endeavor to control and reduce carbon emission and its dire consequences on the planet. On the other hand, the global capital system has become sophisticated and largely driven by financialization of capital a shift of resources from production of goods and services to finance. This paper therefore seeks to explore the benefits and detriments of financialization of capital on climate or green financing. The paper surveys existing literature on financialization and green financing and blends the two concepts to substantiate the discussion. The paper argues that financialization of capital is an impetus for the participation of the private sector in climate financing in spite of the short-term nature of funding in this sector. Another major argument stems from the adverse effects donor funding in that it has a potential of crowding out private sector participation in green financing.

Keywords: financialization, green finance, carbon finance, capital

\section{Introduction}

Climate change and the need for a green knowledge society are topical issues in modern civilization. A green knowledge society is a society that is conversant of climate change issues and their impact on the economy and the planet in general. In spite of this growing need for green knowledge, a major question arises concerning the financing of green projects. On the opposing side to this ever-growing phenomenal of green knowledge society, is the growing shift of resources from production of goods and services to finance. This shift is referred to as financialization of capital. Financialization has been blamed for shifts from equity finance to debt and use of financial markets rather than the production of goods and services (Krippner, 2005). Financialization of capital leads to the dearth of more patient capital in favour of short-term finance and investment, and ultimately speculative bubbles in capital markets. The combination of short-termism in finance and the urgent need to finance green projects may be problematic in trying to combat the effects of climate change world-wide. Indeed governments and multilateral institutions have been spearheading green finance through fiscal intervention and funding initiatives. The question that remains unanswered is whether the private sector can actively participate in green financing amid financialization of capital. This paper therefore seeks to explore the interactions between green finance and financialization of capital in order to ascertain the likely impact of the former on financing green projects. This interaction is what I refer to as 'financialization of green capital'.

\section{Literature Review}

\subsection{Financialization of capital}

Various studies have been conducted on financialization but no consensus has been reached on its definition. For instance, financialization may be defined as the transformation of an increasing number of assets into financial commodities that can be easily traded on liquid markets (Leyshon \& Thrift, 2007). Other scholars define financialization as a gradual shift away from the centrality of traditional intermediary institutions towards disintegrated investment and trading (Sinclair, 2005); a shift in corporate activities from the production of goods and services to the trading of financial assets (Froud, Johal, Leaver, \& Williams, 2006); the increase in the size of financial markets and financial institutions in the modern macroeconomic system (Orhangazi, 2007); and finally as the shift in gravity of economic activity from 
production (and even from much of the growing service sector) to finance (Foster, 2007). The term "financialization" dates back to the early 1990s when Kevin Phillips employed it in his Boiling point (New York: Random House, 1993) and later in 1994 dedicated a key chapter of his Arrogant Capital to the "financialization of America" (Foster, 2007). Foster argues that financialization of capital has its origins in the 1960s. Key figures ascribed to the documentation of the rise in financialization are Harry Magdoff and Paul M. Sweezy in their article "The Dynamics of U.S. capitalism" published in the Monthly Review Press in 1972 (Foster, 2007). This paper subscribes to Foster's definition of financialization which points to the increasing role of finance relative to production of goods and services.

According to neoclassical economic theory financial intermediaries are a major source of primary capital and therefore form the basis of economic development. The surplus funds accumulated by financial intermediaries however seem to have shifted more to supporting the secondary markets rather than the distribution or reallocation of resources to the primary users of capital - the real sectors of the economy. It may further be argued that financialization is a direct result of the nature of the political economy and is prevalent in developed economies (Engelen, 2000).

The importance of finance and in particular financial intermediation has been researched widely, providing varying hypothesis and results. For instance, discussions on finance in economic development date back to the supply-leading hypothesis by Schumpeter in 1912 (Schumpeter, 1912). In a counter argument, Robinson asserts that financial development is endogenously related to the demands of an expanding economy (Robinson, 1952). Thus, growth in finance depended on the extent of economic activity, implying that a growing economy tends to demand more financial services than otherwise. Patrick later argued in his hypothesis that there exists a bidirectional finance-growth relationship (Patrick, 1966). In his hypothesis, the supply-led and demand-following relations are relevant in the study of financialization of capital. The supply-led hypothesis postulates that the surplus funds (finance) propel economic growth as funds are employed to acquire physical capital used in the production of goods and services. The demand-following hypothesis on the other hand, states that the growth of finance is a result of the growing economy and as such economic agents demand funds for the production of goods and services. Thus, the applicable association in any economy is largely dependent on the stage of economic maturity of a country. However, in modern economies, some economists argue that finance drives the real economy (Fase \& Abma, 2003; Levine, 1997). On the other hand, the puzzle on whether nonbank financial institutions complement or compete with the banking industry remains unresolved. Despite the arguments from Levine it can be seen that such assets as money market unit trusts are surely an alternative to bank savings and deposits accounts. Further, it is theoretically fit to say that as investors' preferences change, banks get affected to some extent. Thus, due to demographic changes in society, investors may choose to liquidate their deposits with banks and invest with mutual funds (Saunders \& Cornnet, 2008). Another argument in this regard is that the increased competition for household savings has led to the growth of nonbank financial institutions and hence reduced the profitability of traditional financial instruments (Davis, 2000). Davis provides arguments for this increased competition (disintermediation effect) as taking both the liability and asset side bank-non bank institutions' competition. From a holistic approach, this points to the reduced bank interest margins and the increased desire by banks to venture into investment banking activities so as to earn non-interest income. Regarding competition on the liability side, Davis argues that "money market funds are diversified open-end investment companies that invest in short-maturity and highly-rated debt securities" (pp. 14).

The main drivers are the long-term growth of pension funds and mutual funds and according to the International Monetary Fund there is competition-driven disintermediation in the modern financial system (International Monetary Fund, 2004). These arguments on financial disintermediation supersede those by Levine and colleagues who posit that changes in financial intermediaries are a result of dynamic and complex market structures which only improve financial services, rather than compete with them.

Several other scholarly articles have attempted to measure or model financialization without general consensus on the methods. It is generally accepted that financialization represents a wide spectrum of economic agents and macroeconomic variables. For instance financialization may be measured by the effect of what is termed "financedenominated accumulation regime" in which financialization has to a great extent influenced economic agents such as households, investment, and the foreign sectors (Stockhammer, 2007). On investment, Stockhammer observed that with the expansion of financial instruments, most companies assumed debt and engaged in share buybacks arrangements which led to negative contribution of the stock market to non-financial businesses.

The changes in capitalism over the past three decades, according to Foster (2007) have been characterized by three terms: neoliberalism, globalization, and financialization. The first two terms have widely been discussed over the decades but financialization came to the surface more frequently in the 1990s. It can further be argued that capitalism led to the inefficient and increased devotion of surplus capital to "speculative, casino-like pursuits, rather than long-term 
investment in the real economy" (Tobin, 1984). However, the chief architects of the theory of financialization, Magdoff and Sweezy (1985) claimed that "financialization was functional for capitalism in the context of a tendency to stagnation" in that the casino society does not channel a lot of talent and energy into financial shell games (Magdoff \& Sweezy, 1998). Instead Magdoff (1967) alludes to the financial explosion as resulting from stagnation of the underlying economy which he terms "stagnation thesis".

Financial development, which generally encompasses financialization of capital, has been found to have causal relations with economic growth and financial deepening stimulates economic growth through capital accumulation (Calderon \& Liu, 2003). Against this backdrop, financial development may positively impact on growth through financial accumulation or through changes in technology. Capital accumulation means that enhanced financial systems may attract capital and improve national savings. To attain a positive interaction between economic and financial development, financial liberalization is essential. It may further be argued that for the capitalist economy to continue to grow it must find new sources of demand for the ever increasing surplus that it generates (Foster, 2008).

Radical economists argue that financialization generates stagnation as it is generally associated with rapid economic growth. This group of economists puts forward arguments that suggest slow economic growth during periods of increased financialization especially during the period beginning in the 1980s through to the 2000s. The periods of rapid growth in financialization have resulted in unstable business cycles and prolonged stagnation (Palley, 2007). Palley further argues that financialization renders the economy susceptible to debt-deflation and prolonged recessions and terms this the "financialization thesis".

Foster (2007) puts forward the following arguments against financialization:

- The financialization of the world economy has brought about penetration of emerging market economies and accelerated financial dependence marked by neoliberal globalization policies.

- The financialization of capital has led to a more uncontrollable system that arguably could have resulted in the 2007-9 global financial crises.

- In a more related point, financialization is an on-going process that creates financial bubbles that cannot be controlled by market crashes. This may be traced to the 1987 stock market crash and the 2000 dotcom bubble. The stock markets quickly recovered the losses incurred during the crashes and aggravated new asset bubbles.

Furthermore, according to Palley (2007), the principal effects of financialization are threefold, as follows:

- First, they escalate the importance of the financial sector relative to the real sector;

- Second, they transfer income and wealth from the real sector to the financial sector, and lastly

- they promote income inequality and con tribute to wage stagnation.

Palley (2007), also found three striking sets of conduits through which financialization operates. In a nutshell, Palley is of the view that financialization is bad for growth! These encompass shifts in the structure and operation of financial markets; changes in the behavior of nonfinancial companies and changes in economic policy. The notion of the corrosive influence of the financial markets further points to two levels that support its dominance in the modern economy (Muggie, 2009). Foster (2008) finds that financialization of capital has actually led to bigger bubbles that burst more frequently resulting in devastating aftermaths. Credit expansion and speculative tendencies have been the major feeders from financialization of capital. Expansion of credit feeds into any asset bubble and to what Minsky termed "Ponzi finance" or hyper speculation (Minsky, 1982). Foster (2008) postulates that this hyper speculation is mainly underscored by heavy borrowing used to purchase financial assets and not backed by income streams they will generate but instead backed by the assumption of increasing prices of the underlying assets. Greenspan terms this the "wealth effect" in which the is "the tendency for consumption to grow independently of income due to rising asset prices under financialization" (Greenspan, 1980).

As innovation increases in the financial markets, more financial disintermediation occurs. Disintermediation refers to the substitution of bank finance with the issuance of marketable bonds, securitization of mortgages, loans and any other financial assets (Dore, 2008). This has inevitably led to the reduced dependency on banks by depositors to other financial institutions such as mutual funds, pension funds and insurance companies.

\subsection{Green Finance}

Green financing mechanisms cover both adaption and mitigation initiatives. The Kyoto Protocol established the Adaption Fund which relies on two percent on levy on Clean Development Mechanism (CDM) projects' proceeds (Africa Partnership Forum, 2009). The Adaption Funding relies on market-based carbon finance which falls within the auspices 
of UNFCCC/Kyoto protocol or Conventional funds. CDM seeks to promote sustainable development in developing countries while helping developed parties comply with emission reduction commitments. Other green funding initiatives have been established worldwide and are managed by the World Bank and other multilateral agencies. These initiatives are referred to as non-Convectional funding initiatives. Trading in these unregulated voluntary carbon market has been striving as small project developers who are also heavy emitting firms take advantage of unregulated trading (Africa Partnership Forum, 2009). Carbon trading was estimated at generating USD64 billion in 2007 although this did not signify reduction in emissions as funds remained under the control of the corporate world (The World Bank, 2008; United Nations Population Fund and Women's Environment \& Development Organization, 2009). However transactions in the voluntary carbon markets remain small relative to those in CDM.

The public finance on the other hand should be used as a carrot to attract private capital into green investment (World Economic Forum, 2012). The mobilization of funding for green projects is thus expected to be enhanced by governments and public funding through guarantees, insurance, incentives, and formulating appropriate policies. In China for instance banks have green credit policies and financing green projects is a key part of corporate social responsibility (Banktrack, 2012).

Another way of reducing emissions has been the cautious use of innovation and industrial policy (The World Bank, 2012). This is in light of asset price bubbles which could have long-term effects on the credibility of financial instruments and industrial policies. However innovative financing tools are central to green infrastructure policies and investments although they may lead to abuses and asset bubbles as discussed earlier. The World Bank estimates that green finance from public sources should leverage between USD200 billion and USD400 billion by 2020. As of 2010, USD143 billion of the USD211 billion invested in green projects had been attributed to the private sector (The World Bank, 2012). The challenges of mobilizing funds for green investments include the fact that projects may look unbankable on the onset; projects may have a mismatch with the tenor of funds; and most green projects are massive making cost recovery is difficult (The World Bank, 2012). The other challenge facing most countries is the level of commercial and donor funding for green projects (Ancharaz \& Sultan, 2010). If more funding for green projects is funded through aid it actually reduces commercial level participation. This may arise due to the differences in the cost of funding to the recipients and obviously stakeholder influence would be rife in both circumstances. The World Bank runs a Carbon Finance Unit which championed the Prototype Carbon Fund in 1999 and has 10 funds that operationalize carbon financing (The World Bank, 2009). The creation of carbon funds works in promoting climate change awareness, promotion of green investments and reducing transaction costs associated with dealing with greenhouse gas emissions. However planned green project investments still remain much more than the governments and development institutions can finance (Larson, Ambrosi, Dinar, Rahman, \& Entler, 2008). This therefore requires the active participation of the private sector which may be in surplus financial positions.

At a micro level, climate change financing is vital for developing countries and in particular for small to medium enterprises who rely on micro finance institutions for funding. Promoting awareness of green practices to these firms through micro finance institutions could foster sustainable development (Mckee, 2008). However the promotion of green practices to the poor is not a solution to climate change as this group is the recipient of the climate change consequences. Furthermore, most developing countries remain vulnerable to both climate change and to financialization of capital. First, climate change leads to droughts, famines and floods which hamper food production and selfsustenance. Second, financialization affects developing countries in that in times of crises humanitarian aid dwindles which during rapid economic growth wealth is accumulated by the rich few (Foster, 2007; Leyshon \& Thrift, 2007).

\section{Implications of financialization on green finance}

\subsection{Case for financialization in green economics}

\subsubsection{Financial innovation}

Financialization leads to increased innovations in the financial sector. Thus as the system becomes more financialized, financial markets are bound to create more securitization and derivative securities that subsequently promote the breadth and depth of capital markets. The depth and breadth of financial markets are important in the creating liquidity in the markets which in turn promotes investor participation. Therefore creation of complex and highly liquid securities backed by green assets would increase market liquidity through the multiplier effect. For example green asset backed securities (GABS) may promote awareness and participation in green economic initiatives in the global economy. 


\subsubsection{Emerging field}

Green financing or green financial management is a new but growing field in modern economics. Although participation may emanate from both the private and public sectors of the economy, green financial management may emerge as a new branch in financial economics. This may be strongly supported by financialization of capital through the creation of new liquid assets backed by green assets.

\subsubsection{Efficient allocation of resources}

Financialization leads to speculation. Creating green financial instruments will promote speculation and hence lead to the efficient allocation of resources. As more resources are channelled towards green asset backed securities, market forces would ensure price correction mechanisms are in place to foster a more efficient use of resources. This may be learned from the credit default swaps in the United States which eventually led to a global financial crisis. The participation speculators in the innovative markets will make funding for green projects possible in spite of short-term nature of such funds.

\subsubsection{Competitive advantage in areas of production}

Since literature surveyed suggests that financialization favours financial markets to production of goods and services; it follows that for the production of goods and services to be viable only economic agents with a competitive advantage would produce these goods and services. This further promotes internationalization of production to efficient production economies. Economic agents who are inefficient in the production of goods and services would be starved of capital as agents in surplus funds prefer investing the funds in capital markets to setting up new factories and production lines. Thus financialization would encourage economic agents to concentrate their production only in areas of their competitive advantage. Consequently, carbon and greenhouse emissions would be confined to certain geographic areas making it much easier to control.

\subsubsection{Globalization and integration of financing}

With globalization and integration of financial markets, financing green projects should be much easier. The availability of funds from Euromarkets and international markets should make the issuance of green securities more attractive. This may be enhanced by getting ratings for the green asset backed securities. Appetite for financial products driven by financialization of capital would increase the uptake of green asset backed securities due to the integration of financial markets which promotes investor diversity.

\subsubsection{Expansion in green knowledge society}

Although financialization of capital promotes hyper speculation in the financial markets, investing in green assets is likely to promote green knowledge societies where societies become cognisant of global warming issues. If, for instance governments or development banks issue public green bonds to the public, then the society would learn of climate change issues through advertising and participating in these securities.

\subsubsection{Investment in green/sustainable projects}

The availability and liquidity of green asset backed securities would promote investments in the underlying assets- green projects. This would enhance investments in sustainable projects worldwide. Financialization of capital promotes the creation of securities which should in turn boost the development of the underlying assets.

\subsubsection{Ripple effect on productive sectors}

Investment in green projects should promote investments in other supporting sectors which could boost economic output and reduce unemployment. 


\subsubsection{Development of green indices}

To promote trading in green asset backed securities, financial market regulators and players may promote the establishment of independent green securities trading platforms. Securities may thus be listed in exchanges which may boost investment in green projects and thus reduce carbon and greenhouse gas emissions.

\subsection{Case against financialization in green economics}

\subsubsection{Speculative bubbles in the market}

Creation of innovative securities is likely to lead to asset bubbles which could further destabilize financial markets through bubbles bursts and the contagion effect on the globally integrated financial system.

\subsubsection{White collar jobs creation}

Financialization of capital promotes white collar job creation especially in the financial sector. In emerging markets economies like South Africa where unemployment is driven by low skills base, this may work against the country. The country may have to import labour from neighbouring countries and from abroad to sustain capital market growth arising from financialization of green capital.

\subsubsection{Crowding out other sectors of the economy}

As discussed earlier, financialization tends to drive finance from production of goods and services to financial services like investment in stock markets and other short-term securities. This may in turn hamper the supply of funds to other productive sectors of the economy such as small and medium enterprise firms.

\subsubsection{Increase in cost of capital}

As competition for funds rises due to the demand for green finance instruments the cost of capital for firms would also rise. The increase in cost of capital may manifest in form of increased interest payments or increased required rates of return on investments like equity, bonds and hybrid securities.

\subsubsection{Promotion of socio-economic inequalities}

Like hedge funds, investments into green projects may require large sums of capital which may be out of reach for many. Even if these assets are securitized and unitized the initial investment may still discriminate against some sectors of the society. This will further drive unequal societies which may in turn lead to social unrest in the affected economies.

\section{Conclusion}

This paper explores the benefits and detriments of financializing green capital. Financialization of capital if found to have changed the investment landscape from more patient capital to short-term capital. On the other hand green projects require long-term and stable capital for success. However, green finance still remains at a growth phase where governments, multilateral institutions and the donor community are active in funding green projects. This paper argues that green finance is likely to attract more private sector participation as the world economy becomes more financialized. Innovations in green capital markets are likely to attract an array of investors and make the markets more efficient in allocating resources and highly liquid. Major detriments emanate from the fact that financialization of capital tends to promote unequal societies, and may also crowd out productive sectors. Overall, the paper puts forward more and substantive arguments in favor of financialization of green capital than otherwise. It is thus concluded that financialization of green capital is a panacea to the promotion of both the green knowledge societies and reduction and control of carbon emissions. 


\section{References}

Africa Partnership Forum. (2009). Financial Resources and Investment for Climate Change. APF Special Session. Addis Ababa: UN Economic Commission for Africa.

Ancharaz, V. D, \& Sultan, R.A. (2010). Aid for Trade and Climate Change Financing Mechanisms ICTSD Series on Trade-Supported Strategies for Sustainable Development (Vol. Issue Paper No. 10). Geneva, Switzerland: International centre for Trade and Sustainable Development

Banktrack. (2012). China Sustainable Finance Newletter.

Calderon, C , \& Liu, L. (2003). The direction of causality between financial development and economic growth. Journal of Development Economics, 72 321-334.

Davis, E.P. (2000). Pension funds, financial intermediation and the new financial landscape. Pensions Institute, Discussion Paper P10010.

Dore, R (2008). Financialization of the global economy. Industrial and Corporate Change, 6, 1097-1112.

Engelen, E. (2000). Financialization, Pension Restructuring, and the Logic of Funding. Discussion Paper,. University of Amsterdam.

Fase, M. M.G, \& Abma, R.C.N. (2003). Financial environment and economic growth in selected Asian countries. Journal of Asian Economics, 14, 11-21.

Foster, J.B. (2007). The financialization of capitalism. Monthly Review, 58(11).

Foster, J.B. (2008). The financialization of capital and the crisis. Monthly review, 59.

Froud, J., Johal, S., Leaver, A., \& Williams, K (2006). Financialization and Strategy: Narrative and Numbers. London: Routledge.

Greenspan, A. (1980). The great Malaise. Challenge, 23(1), 38.

International Monetary Fund. (2004). Global Financial Stability Report: Institutional Investors in Emerging Markets (Chapter V, pp. 111151).

Krippner, G. R. (2005). The Financialization of the American Economy. Socio-Economic Review, 3(2), 173-208.

Larson, D.F, Ambrosi, P, Dinar, A, Rahman, S. M, \& Entler, R. (2008). Carbon Markets, Institutions, Policies,and Research. Policy Research Working Paper. The World Bank.

Levine, R. (1997). Financial development and economic growth: Views and agenda. Journal of Economic Literature, 35(2), 688-726.

Leyshon, A, \& Thrift, N (2007). The Capitalism of Almost Everything: The Future of Finance And Capitalism. Theory, Culture and Society, 24(7-8), 97-115.

Magdoff, H, \& Sweezy, P.M (1998). The irreversible crisis. Monthly Review Press, 49.

Mckee, K. (2008). Microfinance: Climate change connections Development Outreach: Special Report: World Bank Institute.

Minsky, H. (1982). Can it Happen Again? New York: : M.E Shape.

Muggie, D. (2009). Tales of tails and dogs: Derivatives and financialization in contemporary capitalism. Review of International Political Economy, 16(3), 514- 526.

Orhangazi, O. (2007). Financialization and Capital Accumulation in the Non-Financial Corporate Sector: A Theoretical and Empirical Investigation of the U.S. Economy: 1973 - 2003. Working paper series number 149. Political Economy Research Institute. University of Massachusetts Amherst.

Palley, T. I. (2007). Financialization: What it is and why it matters. Working Paper. Levy Economics Institute.

Patrick, H.T. (1966). Financial Development and Economic Growth in underdeveloped countries. Journal of Economic Development and Cultural Change, 14, 174-189.

Robinson, J (1952). The generalization of the general theory, in the rate of interest and other essays. London: Macmillan.

Saunders, A, \& Cornnet, M.M (2008). Financial Institutions Management: A Risk Management Approach. (6th Ed.). Singapore: McGraw-Hill International Edition.

Schumpeter, J.A. (1912). The theory of economic development. Cambridge, MA: Harvard University Press.

Sinclair, T. (2005). The new masters of capital. New York: Cornell University Press.

Stockhammer, E. (2007). Some Stylized Facts on the Finance-Dominated Accumulation Regime. Competition and Change, 12(2), 184202.

The World Bank. (2008). State and Trends of the Carbon Market 2008. Washington, DC: The World bank.

The World Bank. (2009). Carbon finance for sustainable development Carbon finance at the World Bank: Annual report. Washington, DC: The World Bank.

The World Bank. (2012). The Way Forward: Inclusive Green growth Policies Tailored to Real-World Challenges. The World Bank Group. Tobin, J. (1984). On the Efficiency of the financial system. Lloyds Bank Review, 153, 1-15.

United Nations Population Fund and Women's Environment \& Development Organization. (2009). Financing that makes a difference Climate Change Connections.

World Economic Forum. (2012). The Green Investment Report -The ways and means to unlock private finance for green growth. Retrieved 25 March 2013, from http://www.weforum.org/reports/green-investment-report-ways-and-means-unlock-privatefinance-green-growth 
